\title{
Bisfenol A İçerikli Rezin Esaslı Dental Materyallerde Bisfenol A Salınımı ve İnsan Vücuduna Östrojenik Etkilerinin İncelenmesi
}

\author{
Investigation of Bisphenol A Release and Estrogenic Effects on Human Body in Resin-Based \\ Dental Materials Containing Bisphenol A
}

Sena GÜRSOY ${ }^{1}$, Ebru EMEKLİ-ALTURFAN²믄

Öz

Dünyada her yıl 5 milyon tonu aşkın üretim kapasitesiyle en çok kullanılan ürün olan Bisfenol A, endokrin bozucu kimyasallar arasında yer almaktadır. Dayanıklı yapısıyla plastikler, gıda saklama kapları, plastik su şişeleri, elektronik cihazlar, metal konserve ve içecek kutularının iç yüzey kaplamaları, bebek biberonları, diş hekimliğinde kullanılan dolgu malzemeleri ve çürükten koruma amaciyla yaygın kullanılan fissür örtücüler gibi çok çeşitli ve yaygın alanda karşımıza çıkmaktadır. Geniş bir yelpazede kullanım alanına sahip olan Bisfenol A, canlılarda ksenoöstrojen olarak etki göstermektedir. Diş hekimliğinde kullanılan bazı materyaller, hava, su, toprak, besinler gibi çeşitli kaynaklardan Bisfenol A ile maruziyet söz konusudur ve bu maruziyetler sonucu vücutta toksik etkiler görülebilmektedir. Bisfenol A ile maruziyetle meydana gelebilecek etkilerin önemli bir halk sağlığ1 problemi olduğu düşünülmekte ve bu konuda yapılan çalışmalar her geçen gün artmaktadır.

$\mathrm{Bu}$ derlemede Bisfenol A'nın yapısı, insan vücudundaki yazgısıyla beraber doz bağımlı östrojenik etkileri, diş hekimliğinde kullanılan kompozit restoratif dolgu materyali ve fissür örtücülerindeki yeri ile Bisfenol A sızıntılarının östrojenik etkileri arasındaki bağlantı incelenmiştir. İncelenen çalışmalar net bir kanıda buluşmasa da, dental tedavilerde kompozit ve fissür örtücü uygulanması ile Bisfenol A ile maruziyeti söz konusu olabileceği ve uzun dönemde sağlık üzerine olumsuz etkileri olabileceği ortaya konmuştur.

Ebru Emekli Alturfan ( $\square$ )

Marmara Üniversitesi, Diş Hekimliği Fakültesi, Temel Tıp Bilimleri Anabilim Dall, Biyokimya, Istanbul, Türkiye.

e-mail:eiemekli@marmara.edu.tr

Sena Gürsoy

Marmara Üniversitesi, Diş Hekimliği Fakültesi, İstanbul, Türkiye.

Submitted / Gönderilme: 15.10.2021

Accepted/Kabul: 19.11.2021
Anahtar Kelimeler: Bisfenol A, kompozit, fissür örtücü, östrojen

\begin{abstract}
Bisphenol A, which is the most used product in the world with a production capacity of more than 5 million tons every year, is among the endocrine disrupting chemicals. With its durable structure, plastics, food storage containers, plastic water bottles, electronic devices, inner surface coatings of metal can and beverage cans, baby bottles, filling materials used in dentistry and fissure sealants that are widely used for decay protection, are encountered in a wide range of and widespread areas. Bisphenol $\mathrm{A}$ has a wide range of uses and acts as a xenoestrogen. There are several exposure routes of Bisphenol A from various sources such as some materials used in dentistry, air, water, soil and nutrients and toxic effects can be seen in the body as a result of these exposures. These effects are considered to be an important public health problem, and studies on this subject are increasing day by day.

In this review, the structure of Bisphenol A, its dose-dependent estrogenic effects along with its fate in the human body, its place in composite restorative filling materials and fissure sealants used in dentistry, and the relationship between the estrogenic effects of Bisphenol A leaks were investigated. Although the studies examined do not meet a clear conclusion, it has been revealed that the application of composite and fissure sealant in dental treatments may lead to Bisphenol A exposure and may have negative effects on health in the long term.
\end{abstract}

Keywords: Bisphenol A, composite, fissure sealant, estrogen

\section{Endokrin Bozucu Kimyasal Maddeler}

Endokrin sistem, vücutta homeostazı sağlamakla ve korumakla görevlidir. Büyüme, cinsel gelişim, uyku, açlık ve besin öğelerinin vücutta kullanımı gibi mekanizmalardaki işlevini hormonlar aracılığıyla yerine getirmektedir. Vücudun temel iletişim ağlarından birini 
oluşturan endokrin sistemde, önce endokrin dokularda hormonlar üretilir ve bu hormonlar diğer dokular arasında iletişimi ve eşgüdümü yönlendiren kimyasal haberciler olarak kana geçerler. Endokrin sistemi kısaca özetlemek gerekirse; beyin, böbreküstü bezleri, pankreas, tiroit, testis veya over gibi organlardan salgılanan hormonları kapsayan karmaşık yapılı bir sistemdir (Fendoğlu ve ark., 2017).

İnsanlarda ve hayvanlarda iç hormonal dengeyi bozan ve geçici ve/veya kalıcı etkilere neden olan bileşiklerin tümü endokrin bozucular olarak isimlendirilmektedir (LagosCabre R ve Moreno R.D, 2012). Endokrin bozucu kimyasallar (EBK) ise; yalnızca hormonların üretimini, salınımını ve taşınmasını değil, bunlarla birlikte hücresel metabolizmayı, bağlanma etkisini ve eliminasyonunu da etkileyen, endojen hormonal sinyalizasyonun herhangi bir yönüne müdahale eden eksojen kimyasallar veya kimyasal karışımlar olarak tanımlanmaktadır (Gore ve ark., 2015; Diamanti ve ark., 2009). EBK'ler; doğal veya insan yapımı kimyasal bileşiklerin hızla büyüyen bir grubudur ve heterojenlerdir (Diamanti ve ark., 2009; Zoeller ve ark., 2012). Doğal veya sentetik yapılı olabilen EBK'lerden; genistein, daidzein ve kumestrol dahil fitoöstrojenler gibi doğal EBK'ler vücuda alındıklarında hızlıca parçalanıp metabolize olmaktadırlar. Bu sebeple de ancak içinde bulundukları gıdaları çok yüksek miktarlarda tüketen kişilerde zararlı etkileri görülmektedir. Sentetik EBK'ler ise endüstriyel birçok alanda kullanımı mevcut olan kimyasal maddeler ve bu kimyasalların yan ürünleri olan bileşiklerdir. Poliklorlu bifeniller, polibromlu bifeniller, dioksinler, bisfenol A (BFA), fitalatlar, pestisitler, bazı ilaçlar ve farmasötik ürünler sentetik EBK bileşiklerine örnek olarak gösterilebilir (Fendoğlu ve ark., 2018).

EBK'lere hava, su, gıda, tüketici ürünleri gibi birden fazla yol ile maruz kalınabilmektedir (Papalou ve ark., 2019). Deriye temas ve/veya soluma ile (örn; parabenler, kozmetikler, çeşitli ilaçlar), su veya besinler aracılığıyla oral yoldan (örn; BFA, ftalatlar) ve plasentadan ve emzirme esnasında anne sütünden biyolojik yol ile de EBK'lere maruziyet söz konusudur (Kabir ve ark., 2015; Fendoğlu ve ark., 2017). EBK'lerin hormonlara benzeyen kimyasal yapılarıla veya farklı yolaklar ile hormonların işleyişine etki ettikleri ve endokrin sistemde bazı fonksiyonları değiştirerek insanlarda ve hayvanlarda toksik etkiler oluşturdukları görülmüştür (Bergman ve ark., 2013). EBK'lerin tiroit hormon reseptör agonisti veya antagonisti olarak etki gösterebildiği, bunun yanında EBK'lerin çoğunluğunun östrojenik, androjenik ve antiandrojenik etkilerinin olduğu bilinmektedir (Diamanti ve ark., 2009).
Östrojenitaklitederekveya daha farklı etkimekanizmaları ile canlılarda endokrin bozucu etkiler oluşturan çeşitli çevresel kimyasal maddeler "ksenoöstrojen" olarak isimlendirilmektedir. Ksenoöstrojenlerden bazıları hormon reseptör bölgelerine bağlanarak hormonların kendileri gibi davranışlar sergilerken; diğer bir kısmı ise hormonların kendilerine özgün reseptör bölgelerine bağlanmalarını engelleyerek anti-hormonal etkiler ortaya çıkarmaktadır (Bondesson ve ark., 2009). Deterjanlar, farmasötik bileşikler, metaller, plastikleri sertleştirmek için kullanılan bazı kimyasallar ve BFA ksenoöstrojen kaynakları arasında sayılabilir (Öz, 2020).

\section{Bisfenol A’nın Yapısı, Özellikleri ve Kullanım Alanları}

Günümüzde, dünyada her yıl 5 milyon tonu aşkın üretim kapasitesiyle en çok kullanılan ürün olan BFA, ilk olarak Rus kimyager Dianin tarafindan 1891'de sentezlenmiş; 2,2-bis(4-hidroksifenil) propan yapısına sahip; kat1, beyazkrem renklerde, fenolik kokulu ve kristal yapılı bir bileşiktir (Şekil 1). Etanol, aseton ve dimetilsülfoksid (DMSO) gibi organik sıvılarda çözünürlüğü yüksek iken suda çözünürlüğü düşüktür (İnce, 2017; Battal, 2012; Zemheri ve Uğuz, 2018).

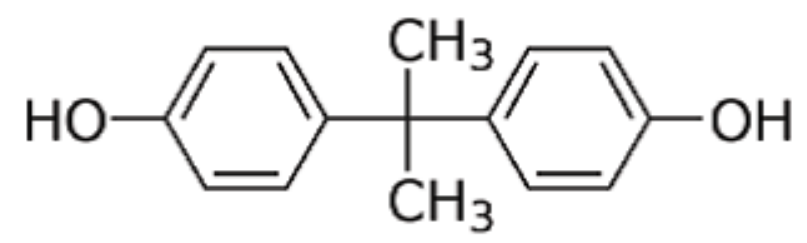

Şekil 1. BFA'nın Kimyasal Yapısı.

BFA çoğunlukla tekrar kullanılabilen, kalın, dayanıklı, şeffaf plastik ürünlerin yapısında yer almaktadır. Günlük yaşantımızda kullandığımız polivinil klorür (PVC) plastikler, gıda saklama kapları, damacana ve plastik su şişeleri, gözlük camları, CD, DVD gibi elektronik cihazlar, kompakt diskler, termal kağıtlar, metal konserve ve içecek kutularının iç yüzey kaplamaları, bebek biberonları, inşaat sektöründe beton restorasyonu ve korunmas1, fiberglas üretimi, otomotiv sektöründe elektronik parçalar, diş hekimliğinde kullanılan dolgu malzemeleri ve Pedodonti'de çürükten koruma amacıyla yaygın kullanılan fissür örtücüler BFA ihtiva eden birçok ürün arasında örnek olarak gösterilebilir (İnce, 2017; Akyüz ve ark., 2011). 
Paketleme uygulamalarında kullanılan kimyasal maddeler yedi ayrı gruba ayrılmaktadır (Tablo 1). 1 (PET), 2 (YYPE), 4 (DYPE), 5 (PP) ve 6 (PS) numaralı gruplar polimerizasyon ya da paketleme uygulamalarında bisfenol içermezken; 3 (PVC) numaralı grup BFA içerebilir ve "diğer" olarak adlandırılan 7 numaralı grup BFA monomerinden yapılan polikarbonat ve epoksi gibi malzemeleri içermektedir. BFA içermeyen grupların gıdalara teması ile besin maddelerine BFA geçişi söz konusu olmazken, BFA içeren grupların gıdalara teması ile besinlere BFA geçtiği bilinmektedir. Normal şartlar altında bu tip malzemelerden belirli oranlarda BFA salınımı mevcutken, plastikler sıcağa maruz kaldıklarında ve/veya plastikler zarar gördüğünde gıdalara BFA geçişinde artış meydana gelmektedir (Akyüz ve ark., 2011).

Tablo 1. Paketleme ve uygulamalarında kullanılan plastikler ve kodları (Sevencan ve Vaizoğlu, 2007)

\begin{tabular}{|c|c|c|c|}
\hline $\begin{array}{l}\text { Dönüşüm } \\
\text { No }\end{array}$ & Kisaltma & Polimer İsmi & Kullanımı \\
\hline 1 & $\begin{array}{l}\text { PETE ya da } \\
\text { PET }\end{array}$ & $\begin{array}{l}\text { Polietilen } \\
\text { Tetrafitalat }\end{array}$ & $\begin{array}{l}\text { Poliester fiberler, film, } \\
\text { elyaf, köpük, şişe, katı } \\
\text { cisim }\end{array}$ \\
\hline 2 & YYPE & $\begin{array}{l}\text { Yüksek } \\
\text { yoğunluklu } \\
\text { polietilen }\end{array}$ & $\begin{array}{l}\text { Taşınmaya elverişli } \\
\text { kapların yapımı, çeşitli } \\
\text { şişeler, çantalar, oyun } \\
\text { alanı malzemeleri }\end{array}$ \\
\hline 3 & PVC ya da V & Polivinil klorür & $\begin{array}{l}\text { Çit ve parmaklık } \\
\text { malzemeleri, yiyecek diş1 } \\
\text { şişeler }\end{array}$ \\
\hline 4 & DYPE & $\begin{array}{l}\text { Düşük } \\
\text { yoğunluklu } \\
\text { polietilen }\end{array}$ & $\begin{array}{l}\text { Sera örtüsü, film, ambalaj, } \\
\text { elektrik sanayi }\end{array}$ \\
\hline 5 & PP & Polipropilen & $\begin{array}{l}\text { Plastik şişe, elektrik } \\
\text { sanayi, mutfak eşyası }\end{array}$ \\
\hline 6 & PS & Polistiren & $\begin{array}{l}\text { Oyuncak, video } \\
\text { kaset, tepsiler, yalitım } \\
\text { malzemeleri }\end{array}$ \\
\hline 7 & Diğer & $\begin{array}{l}\text { Akrilik, } \\
\text { polikarbonat, } \\
\text { naylon } \\
\text { dahil diğer } \\
\text { plastikler }\end{array}$ & \\
\hline
\end{tabular}

Dodds ve Lawson tarafindan BFA'nın insanlarda ve hayvanlarda östrojen reseptörüne (ER) bağlandığ 1 1930'larda bildirilmiştir (Dodds ve Lawson, 1936). Yapılan çalışmalarla atmosfere yıllık 100 tondan fazla BFA salınımı yapıldı ̆̆ tespit edilmiştir (Durmaz ve Giray, 2013). Üretim miktarının çok yüksek olması ve olağanüstü geniş bir yelpazede kullanım alanının bulunması ve bunların yanında BFA'nın düşük konsantrasyonlarda bile insan sağlığı üzerinde ksenoöstrojen olarak zararlı etkilerinin bulunması, çevreye BFA yayılımı ve günlük yaşamda insanların BFA ile teması konularına çok dikkat edilmesi gerektiğini gözler önüne sermektedir (Wioletta ve ark., 2020; Battal, 2012).

\section{Bisfenol A ile Maruziyet Yolları}

Yüksek üretim miktarı ve geniş kullanım alanlarına sahip bir madde olan BFA'nın günlük hayatta popülasyon ile temas riski de oldukça yüksektir (Olea ve ark., 1996; Vandenberg ve ark., 2010; Vandenberg ve ark., 2012; Vandenberg ve ark., 2013; Kang ve ark., 2007). İnsanların BFA'ya maruziyetinin en yaygin yolu BFA ile kontamine olmuş gıda ve içme sularının tüketilmesidir. Besinlerin mikrodalgaya uygun olmayan kaplar ile mikrodalga firınlarda 1sıtılması veya pişirilmesi, besinlerin pişirilmeden veya isıl işlem görmeden önce plastik poşetler ile sarılması BFA maruziyetini arttıran uygulamalar arasında sayılabilmektedir. Bunların dışında çevresel, tıbbi (BFA ile kontamine araç-gereçler) ve mesleki (solunum ile, deri teması ile, üretim işlemleri sırasında yutma vb) yollar ile de BFA'ya maruz kalınabilmektedir (Stahlhut ve ark., 2009; Geens ve ark., 2012).

BFA, diş hekimliğinde kullanılan rezin esaslı dental materyallerin monomerlerinden biridir. $\mathrm{Bu}$ materyallerin ağız içinde uygulanması ile polimerize olmamış monomer çözülebilmekte ve birkaç yol ile vücuda girebilmektedir. Gastrointestinal sistem aracıllı̆ı ile, deriden emilerek, dentin tübülleri aracılı̆̆ ile pulpaya ulaşarak ve solunum ile BFA'ya maruziyet ve olası toksik etkiler görülebilmektedir. Yukarıda sayılan ilk üç yol ile hasta etkilenirken, dördüncü yolda hastayla birlikte diş hekimi ve yardımcı personeli de etkilenmektedir (Akyüz ve ark., 2011).

Tolere edilebilir günlük alım miktarı (TDI); bir maddenin, vücut ağırlığı temel alınarak ifade edilen, tüm yaşam boyunca herhangi bir risk olmadan her gün tüketilebilir olan miktarı olarak tanımlanmaktadır (Durmaz ve Giray, 2013). 1988'de Çevre Koruma Ajansı (EPA) BFA alımında ilk güvenlik standardını $50 \mu \mathrm{g} / \mathrm{kg}$ vücut ağırlığı/gün olarak belirlemiştir. Avrupa Gıda Güvenliği Otoritesi (EFSA) ise Ocak 2015'te yayınladığı raporla bu TDI'yi önemli ölçüde düşük ve geçici olan $4 \mu \mathrm{g} / \mathrm{kg}$ vücut ağırlığı/gün seviyesine revize ederek BFA'nın olumsuz sağlık etkilerine ilişkin büyük bir belirsizliğe işaret etmiştir. EFSA bu raporunda, "BFA'nın meme bezi, üreme, metabolik, nörodavranış ve bağışıklık sistemleri üzerindeki potansiyel sağlık etkilerini çevreleyen belirsizlikler" hesaba katılarak BFA'nın TDI değeri 50 'den $4 \mu \mathrm{g} / \mathrm{kg}$ vücut ağırlığı/gün'e düşürülmesine 
rağmen; BFA maruziyetinden kaynaklanan tüketici sağlığı riski olmadığını da ifade etmektedir. Yine EFSA, yetişkinler için diyet ve diyet dışı kombine maruziyetin 1,449 $\mu \mathrm{g} /$ kg vücut ağırlığı / gün olduğunu tahmin etmektedir ki bu, mevcut geçici TDI'den yaklaşık 3 kat daha düşüktür (Löfroth ve ark., 2019; https://www.efsa.europa.eu/en/ press/news/150121, Erişim Tarihi: 20 Kasım 2020). Amerikan Gıda ve İlaç Dairesi (FDA) 2010'da yayınladığ 1 raporda, BFA'nın anne karnındaki çocuklarda ve çocukluk çağında zararlı etkileri olabileceğini ifade etmiştir. Yine o yıl Kanada, BFA'nın toksik bir madde olduğunu ilan eden ilk ülke olmuştur. Takip eden sonraki dönemlerde dünyada birçok ülke özellikle biberonlarda BFA kullanımına yasaklamalar getirmiştir. Haziran 2011'de ülkemizde yürürlüğe giren Tarım ve Köyişleri Bakanlığı'nın “Türk Gida Kodeksi Gida Maddeleri ile Temasta Bulunan Plastik Madde ve Malzemeler" tebliğine göre; referans numaras1 "13480" olan "2,2-bis (4-hidroksifenil) propan", Türk Gıda Kodeksi (TGK) - Bebek Formülleri ve TGK-Devam Formülleri Tebliğleri'nde bebek olarak tanımlanan tüketici grubu için kullanılan, polikarbonat madde ve malzemelerin üretiminde kullanılmaması belirtilmiştir (Durmaz ve Giray, 2013).

\section{Bisfenol A’nın Organizmadaki Yazgısı}

BFA ile ilgili yapılmış olan biyotransformasyon çalışmalarının pek çoğu deney hayvanları üzerinde gerçekleştirilmişken; insanlarda yapılan çalışma sayısı etik sebeplerle oldukça azdır ve kazayla temas eden kişiler veya gönüllüler üzerindedir. $\mathrm{Bu}$ sebeple de BFA'nın organizmada metabolik yoluyla ilgili birçok bilinmeyen nokta bulunmaktadır (Vandenberg ve ark., 2009). Oral yolla vücuda alınan BFA gastrointestinal sistem tarafindan emilmektedir ancak bu emilimin oranı ile ilgili net bir bilgi bulunmamaktadır. BFA ile deri yoluyla temas sonucu \%10'a yakın bir oranda emilim gerçekleşebileceği gösterilmiştir. Bunların dışında inhalasyon yoluyla da BFA'ya maruziyet söz konusudur (Shelby, 2008; Durmaz ve Giray, 2013).

Oral yolla vücuda alınan BFA; rahim, testis veya fetüs gibi çeşitli doku ve organlara ulaşmadan önce gastrointestinal sistemden ve karaciğerden geçmektedir. BFA memelilerde glukuronidasyon ve sülfatlama yoluyla metabolize edilebilmektedir. Glukuronidasyon işlemi; lipofilik substratların hidrofilik moleküllere dönüştürülerek safra ve idrar yoluyla atılmasının sağlandığı eliminasyon işlemi olarak ifade edilmektedir. Yani BFA glukuronidasyon ile östrojenik aktivite içermeyen hidrofilik bir yapıya metabolize edilir (Öz, 2020). Yapılan çalışmalarda, rodentlere oral yolla BFA verilmesini takiben, BFA'nın hızlı bir şekilde glukuronize edildiği, büyük bir kısmının plazma proteinlerine bağlandığı ve safra ile atıldığı görülmüş̧ür. $\mathrm{Bu}$ sırada birkısım BFA'nın ince bağırsaktan absorbe edilip tekrar kana karıştığı ve BFA'nın büyük kısmı feçes ile atılana kadar birkaç gün bu enterohepatik sirkülasyonun tekrarlandığı da gözlemlenmiştir (Otlu ve Türköz, 2016). İnsanlarda ise oral yolla alınan BFA gastrointestinal sistemden emildikten sonra karaciğerde CYP2C18, CYP2C19 ve CYP2C9 enzimleri ile metabolize edilir ve böylelikle karaciğerden ilk geçişte eliminasyona uğrar. Devamında glukuronik asit ve sülfat ile konjuge olarak ana metaboliti olan BFA glukuronit (BFAG) ve minör metaboliti BFA sülfat oluşur. BFA vücuda alındıktan sonra yarılanma ömrünün yaklaşık 6 saat olduğu ve yaklaşık 42 saatte tamamına yakınının idrarla atıldığı bildirilmiştir. BFA'nın \%9.5'inin hiç değişmeden, $\% 69.5$ 'inin BFAG formunda ve \%21'inin de BFA sülfat konjugatları formunda idrarla atıldığı görülmüştür (Shelby, 2008; Ye ve ark., 2011). BFA metabolitlerinin atılımı idrar yoluyla (\%13-28) gerçekleşirken, serbest BFA esas olarak dışkı yoluyla (\%56-82) atılmaktadır (Kang ve ark., 2006). Serbest BFA'nın asıl endokrin bozucu etkiyi gösteren form olduğu, metabolitlerin hormonlarla etkileşmediği çalışmalarla gösterilmiştir (Snyder ve ark., 2000; Willhite ve ark., 2008). BFA çok hızlı metabolize olmasına rağmen, araştırmalarda yetişkin ve çocukların idrarının haricinde hamile kadınların serumunda, göbek kordonu serumunda ve anne sütünde serbest BFA görüldüğü bildirilmiştir. BFA vücuda alındıktan sonra yağ doku gibi çeşitli dokularda birikebilmektedir (Fernandez ve ark., 2007). Plasenta ve diğer bazı dokularda bulunan beta-glukronidaz enzimi ile BFA metabolitleri dekonjuge olabilmekte veya arilsülfataz c enzimi ile sülfatın inaktivasyonu sonucu konjuge olmayan serbest BFA'ya geri dönüşüm görülebilmektedir (Ginsberg ve Rice, 2009). Serbest BFA birikimi ve dağılımındaki oranın artması, insan sağlığındaki riski de önemli ölçüde arttırmaktadır (Öz, 2020).

\section{Bisfenol A ve Metabolitleri Vücutta Hangi Yöntemlerle Analiz Edilir?}

BFA, lipofilik yapısı sebebiyle insan vücudunda yağ dokularda birikebilmektedir. Yapılan çeşitli araştırmalarda insan serum ve çeşitli dokularında, fetal (kordon) serum, plasenta, amniyotik sıvı, anne sütü, hamile kadınların idrar örnekleri, tükürük gibi biyolojik sıvılarda BFA 
tespit edildiği bildirilmiştir (Welshons ve ark., 2006; Ye ve ark., 2009; Ye ve ark., 2008; Fernandez ve ark., 2007). Toplanan biyolojik örneklerden BFA ve metabolitlerinin miktarlarını analiz etmeye yardımcı pek çok yöntem bulunmaktadır. Enzyme-Linked Immunosorbent Assay (ELISA), Yüksek Performans Sıv1 Kromatografisi (HPLC), Gaz Kromatografisi Kütle Spektrometrisi (GC/MS) bu analitik yöntemler arasında sayılabilmektedir. ELISA basit, ekonomik ve pahalı ekipman gereksinimi olmayan bir test olmasına rağmen standardizasyon problemleri, idrar, kan, tükürük gibi biyolojik örneklerde bulunabilen diğer bileşiklerle çapraz tepkime, örneklerden düşük BFA ölçümü gibi sebeplerle güvenli kullanımı zorlaştırmaktadır. Bir süre önce BFA miktarının belirlenmesi amacıyla yenilenmiş bir ELISA yöntemi geliştirildiği bildirilmiş olmasına rağmen performansa dair data bulunmamaktadır. Yayınlanan çalışmalarla, çeşitli analiz cihazlarının haricinde biyolojik örnekleri değişik hazırlama prosedürleri de kullanılmıştır. Örneğin kimi çalışmalar BFAG ve BFA sülfatın ayrışması için glukuronidaz ve/veya sülfatazdan yararlanırken kimisinde sadece BFA saptanmıştır (Battal, 2012).

\section{Bisfenol A’nın Sağlık Üzerine Etkileri}

BFA'nın vücutta ksenoöstrojen olarak üreme, infertilite, doğum ağırlığı ve süresi, pubertal gelişim, büyüme, vücut gelişimi, beyin gelişimi, davranışlar, tiroid hormonları, kardiyovasküler hastalıklar, obezite, diyabetes mellitus, meme dokusu ve çeşitli kanserlerle ilişkilendirilmesi gibi etkileri ve etkileşimleri bilinmektedir (Akyüz ve ark., 2011; Öz, 2020; Battal, 2012; Ayazgök ve Küçükkılınç, 2017; Sözlü ve Akdevelioğlu, 2018; Otlu ve Türköz, 2016; Durmaz ve Giray, 2013; Fendoğlu ve ark., 2018; Yaman ve ark., 2015). Ayrıca BFA'nın düşük dozlarda dahi endokrin sistem üzerinde olumsuz etkileri olduğu da tespit edilmiştir (Ayazgök ve Küçükkılınç, 2017).

BFA ile maruziyette organizmada ortaya çıkabilecek etkilerde maruziyet yaşı, gecikmiş etkiler, karışım etkileri, alışılmamış doz-yanıt ilişkisi, epigenetik ve genotoksik etkiler değişikliklere sebep olabilmektedir. Bunlar arasından en kritik faktör maruziyet yaşıdır; özellikle de prenatal ve erken postnatal dönemdeki maruziyetler toksik etkilerin daha da şiddetli görülmesine sebep olabilmektedir (Fendoğlu ve ark., 2017).

BFA anneden bebeğe plasenta aracılığıyla kolaylıkla geçebildiğinden BFA maruziyeti fetal hayattan itibaren başlamaktadır (Gao ve ark., 2015). Bebekler BFA ile temasta en hassas grup kabul edilmektedir (Otlu ve Türköz, 2016). Yapılan hayvan çalışmalarında, aktif yapıdaki BFA'nın plasenta ve fetal dokularda yüksek konsantrasyon düzeylerine erişebildiği tespit edilmiş ve bu seviyelerin fetüsün gelişimini etkileyebileceği iddia edilmiştir (Vom Saal ve ark., 2014).

Prenatal dönemde BFA'ya maruziyetin gebelik ve doğum üzerindeki etkileri tartışmalıdır. Veiga-Lopez ve arkadaşları yapmış oldukları bir çalışmada hamileliğin ilk trimesterinde yüksek doz BFA maruziyetinin doğum ağırlığında cinsiyete özgü bir azalma ve gebelik süresinin uzunluğundaki artış ile ilişkili olduğunu tespit etmişlerdir. Düşük doğum ağırlığı, olumsuz sağlık sonuçlarıyla ilişkili olduğundan, gebeliğin erken dönemlerinde BFA düzeylerinin doğum ağırlığını azaltma yönündeki etkisi, BFA'nın gelişimsel olarak oluşturduğu riski vurgulamaktadır (Veiga-Lopez ve ark., 2015).

Beyin gelişiminde östrojen ve progesteron mühim bir görev üstlenmektedir. Östrojen nöron gelişimini düzenlemekte ve büyümeyi arttırmaktadır. Araştırmacıların ortaya koymuş olduğu pek çok çalışma ile BFA'nın ksenoöstrojen tesirinin beyin gelişimi esnasında cinsel farklılaşmadan mesul kısımlarda değişikliklere vesile olduğu, öğrenme azlığı ve hafiza bozukluklarına da sebep olabileceği görülmüştür. Ayrıca BFA'nın somatostatin reseptörlerinde modifikasyonlar meydana getirerek büyüme hormonu ve tiroid stimülan hormon (TSH) eksiltici hüküm gösterebildiği bilinmektedir. Elde edilen bu sonuçlar BFA'nın beyin gelişimine zarar verici etkisi olduğu düşüncelerini destekleyici niteliktedir (Durmaz ve Giray, 2013; Battal, 2012).

Tiroid bezinden tiroksin (T4) ve triiyodotironin (T3) formunda salınan tiroid hormonları, hücre farklılaşması, büyüme, gelişme, enerji dengesi, oksijen tüketimi ve metabolik işlevlerin düzenlenmesi gibi tüm dokuların normal fonksiyonu için gerekli ve kritik öneme sahip hormonlardır. Dolayısıyla bu hormonlarda veya metabolizma ve fizyolojilerinde meydana gelen herhangi bir değişiklik, gelişim bozukluğu, mental retardasyon ve nörolojik hastalıklar gibi ciddi sağlık sorunlarına sebep olabilmektedir (Yaman ve ark., 2015). Tiroid fonksiyonlarını bozan çeşitli kimyasal ajanlar ile tiroid bezi işleyişi arasında keskin bir bağlantı kurulamamıştır ancak bazı çalışmalarda bu kimyasalların tiroid hormon analoğu gibi davranabildiği veya tiroid reseptörlerine bağlanarak sinyalizasyonu bozabildiği tespit edilmiştir (Colborn, 2004; McKinney ve Waller, 1994; McKinney ve Waller, 1998;Zoeller, 2005). BFA 
ve tiroid hormonları arasındaki ilişkiyi gözlemleyebilmek için yapılan hayvan çalışmalarında çelişkili sonuçlara varılmışıı ancak BFA'nın tiroid reseptörleri ile zayıf da olsa bağ kurarak T3 antagonisti gibi davranışlar sergileyebildiği de tespit edilmiştir (Yaman ve ark., 2015; Freitas ve ark., 2011; Moriyama ve ark., 2002; Sun ve ark., 2009). İnsan çalışmalarında ise BFA'nın beyinde tiroid ile ilgili genlerin ekspresyonunu arttırabileceği gözlemlenmiş ancak ortaya çıkabilecek değişikliklerin altında yatan tüm sebeplerin aydınlatılamadığı da belirtilmiştir (Zoeller ve ark., 2005; Seiwa ve ark., 2004). Sonuç olarak, BFA'nın tiroid ile ilgili etkilerinin kesin sonuçlarına henüz ulaşılamamıştır, araştırma sonuçlarında çelişkiler olduğu bilinmektedir (Yaman ve ark., 2015).

Üzerinde BFA'nın da etkisi olduğu kanıtlanmış bir başka metabolik bozukluk obezitedir. Gıda ve enerji tüketiminde odak noktada görev alan ve adipositlerde yağ birikimini engelleyen madde östrojendir. Yetişkin bireylerde östrojen düzeylerinin yükselmesi besin alımında azalma ve dolayısıyla kilo kaybı ile bağlantılı iken; östrojen düzeyinin azalması menapoz ve kilo alımı ile bağlantılıdır. Farklı dokularda bu aktiviteler BFA seviyelerinden de etkilenmektedir (Otlu ve Türköz, 2016). Yapılan hayvan çalışmalarında prenatal dönemde BFA dahil endokrin bozucu kimyasallara maruziyet ile farelerde obezite prevalansı, bozulmuş glikoz toleransı ve lipid metabolizması arasında bir ilişki olduğu gösterilmiştir (Konieczna ve ark., 2015). Erişkin farelerle yapılan başka bir çalışmada, oral veya intravenöz yolla düşük doz BFA maruziyeti sonrası farelerde insülin direnci geliştiği görülmüştür (AlonsoMagdalena ve ark., 2010). 2003-2006 yılları arasında 1874 yaş aralı̆̆ındaki 2747 ABD'li erişkinin idrar BFA düzeyleri değerlendirildiğinde, obezite ile bu düzeyler arasında anlamlı bir ilişki görüldüğü bildirilmiştir (Carwile ve Michels, 2011). Başka deneysel çalışmalarda da düşük doz BFA maruziyetinin adiposit sayısında azalmaya sebep olurken mevcut adiposit hacimlerinde artış gerçekleştiğinin görülmesi, BFA ile obezite arasında ilişki olduğunu kanıtlar niteliktedir (Otlu ve Türköz, 2016).

BFA'nın kardiyovasküler sistem ve tip 2 diyabet üzerinde etkilerini gözlemlemek için de birçok araştırma yapılmıştır (Marmugi ve ark., 2014). Anjina, hipertansiyon, kalp krizi, koroner hastalıklar ve çeşitlik kardiyovasküler hastalıklar ile insanlarda idrarda BFA seviyesinin yüksek olması arasında anlamlı bağlantılar tespit edilmiştir. Farelerde BFA'ya akut bir şekilde maruz kalındığında aritmi, kronik şekilde maruz kalındığında ise ateroskleroz ve bozulmuş tansiyon verileri ile karşılaşıldığını gösteren çalışmalar mevcuttur (Otlu ve Türköz, 2016). Uzun süre BFA dozlarına maruz birakılan hayvanlarda hiperkolesterolemi, hiperglisemi ve bozulmuş insülin direnci ile karşılaşıldığ 1 da bildirilmiştir (Otlu ve Türköz, 2016; Marmugi ve ark., 2014). Pankreatik beta hücre işleyişlerini düzenleyen östrojen reseptör alfanın, ksenoöstrojen özellikteki BFA ile aktive olması ile insülin salgılanmasında aşırı artışa sebep olduğu ve böylelikle diyabet, hipertansiyon ve dislipidemi gibi sağlık sorunlarının oluşma riskinin arttığı da bildirilmektedir (LaKind ve ark., 2014).

EBK'lerin farklı türlerinin üreme sisteminin normal yapısına zarar verdiği ve testis ve yumurtalık anomalilerine neden olduğuna dair birçok in vitro ve in vivo kanıt mevcuttur (Miller ve Sharpe, 1998; Fendoğlu ve ark., 2017). İnfertilite; ortalama 12 ay ve üzeri için zamanlanmış korunmasız cinsel ilişki sonrası başarılı bir gebelik oluşmaması olarak tanımlanmaktadır. Çiftlerin yaklaşık $\% 10-15$ 'inde infertiliteye rastlanmaktadır ve bu vakaların \%35'e yakını kadınsal faktörlerden kaynaklanmaktadır (Sözlü ve Akdevelioğlu, 2018). 70 infertil ve 83 fertil erkeğin dahil edilmiş olduğu bir çalışmada, büyükşehirlerde yaşan infertil erkeklerde BFA seviyesinin fertil erkeklerdeki BFA seviyesinden bir hayli fazla olduğu gözlemlenmiştir. Büyükşehirlerde yaşayan erkeklerde BFA miktarının fazla tespit edilmiş olması, bu bölgede BFA kullanımının fazla olduğunun, gıda ticaretinde ve paketleme ürünlerinde kullanıldığının ve dolayısıyla BFA ile maruziyetin yüksek olduğunun göstergesidir (La Rocca ve ark., 2015). Caserta ve arkadaşlarının 18-40 yaş aralığında 48 infertil kadın ve 13 fertil kadın kontrol grubu ile yapmış oldukları bir başka çalışmada infertil kadınların serum BFA seviyesinin anlamlı düzeyde daha fazla olduğu bulunmuştur (Caserta ve ark., 2013). Bunlar ve benzer çalışmaların sonuçları incelendiğinde BFA'nın infertiliteye etki edebileceği sonucuna varılabilmektedir.

48 adet EBK'nin mutajenisite ve karsinojenisite ile yakından alakalı olduğu bildirilmiştir (Choi ve ark., 2004). Meme kanseri kadınlarda en sık, her iki cins için ise ikinci en sık görülen kanser türüdür (Fendoğlu ve ark., 2018). Son y1llarda meme kanserine neden olan temel etken olarak ksenoöstrojenler gösterilmektedir (Davis ve ark., 1993). Çeşitli araştırmaların sonuçlarına göre BFA'nın meme kanseri ile yakından ilişkili olduğuna dair kanıtlar vardır (Soto ve Sonnenschein, 2010). Deneysel araştırmaların sonuçlarına göre meme dokusu üzerinde kötü huylu dönüşümlere neden olabilen kimyasal ajanlar arasında BFA 
da gösterilmektedir (Fendoğlu ve ark., 2018). BFA'nın Tgf- $\beta$ sinyalizasyonunu engelleyerek kanser hücrelerinin çoğalması ve büyümesini desteklediği kanıtlanmıştır (Park ve Choi, 2014).

Ksenoöstrojenlere maruziyet sadece insanlarda değil vahşi yaşamda da üreme döngüleri ve gelişimleri gibi doğal süreçleri bozarak etki gösterebilmektedir. BFA'nın vahşi yaşamda varlığı ve biyoakümülasyonu neredeyse tüm dünyadan bildirilmektedir (Corrales ve ark., 2015).

\section{Bisfenol A ve Östrojen}

Steroid yapılı bir hormon olan östrojen, östrojen reseptörü (ER) olarak adlandırılan reseptör tarafindan hedef hücrelerde yüksek afinite ve spesifite ile tutunabilmektedir. ER, östrojen ile bağlandıktan sonra, reseptörün kromatin ile etkileşime girmesine ve hedef genlerin transkripsiyonunu modüle etmesine izin veren konformasyonel bir değişime uğramaktadır (Kuiper ve ark., 1998). Daha sonra ERöstrojen kompleksi nükleus içine yer değiştirmekte ve östrojen ile dolu ER reseptörü gen transkripsiyonunu modüle edebilmek için ek faktörler ve transkripsiyon başlatma kompleksi komponentleri ile etkileşime girmektedir (Şekil 2) (Gould ve ark., 1998). ER, çeşitli doku tiplerinde mevcut olabilmekteyken; alt tipleri aynı doku içinde farklı hücre tiplerinde mevcut bulunabilmektedir. ER'nin, ER $\alpha$ ve ER $\beta$ olmak üzere iki alt tipi vardır. ER $\alpha$ ve ER $\beta$ proteinlerinin bağlanma ve fonksiyonel özellikleri, östrojen hormonuna benzeyen herhangi bir ligandın yanlış tanınmasından etkilenebilmektedir. ER $\alpha$ uterus, prostat stromas1, yumurtalık, testis Leydig hücreleri, epididim, kemik, meme, beyin, karaciğer, yağ doku gibi yerlerde bulunurken; ER $\beta$ kolon, prostat epitel dokuları, yumurtalık granulozası, kemik iliği, tükürük bezleri, vasküler endoteli gibi dokularda yer almaktadır (Mahamuni ve Shrinithivihahshini, 2019). Östrojenin ER $\alpha$ ile bağlanması hücreleri proliferasyona yönlendirirken, ER $\beta$ sinyalizasyonu proliferasyonu inhibe etmektedir, yani ER $\alpha$ ve ER $\beta$ arasındaki dengenin korunması östrojen aracılı hücre çoğalması ve ölümünde önemlidir (Ayazgök ve Küçükkilinç, 2017; Gould ve ark., 1998). Kapsamlı çalışmalarda bazı sentetik östrojenlerin ve doğal yolla oluşan steroid ligandların ER $\alpha$ 'ya ER $\beta$ 'ya göre farklı rölatif afiniteleri olduğu gösterilmiş olsa da; çeşitli antiöstrojenler dahil çoğu ligandın her iki ER alt tipine de benzer afinitelerde bağlandığ 1 bilinmektedir (Kuiper ve ark., 1998).
BFA yapısal olarak $17 \beta$ estradiol (östrojen hormonu) ile benzerlik göstermektedir (Şekil 3). Bu benzerliğin bir sonucu olarak BFA, ER ile agonist olarak etkileşime girebilmekte ve ekspresyonlarda değişikliğe sebep olabilmektedir (Mahamuni ve Shrinithivihahshini, 2019).

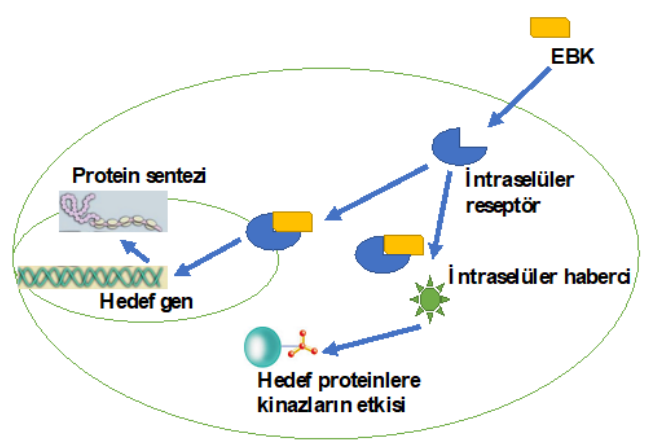

Şekil 2. İntraselüler reseptörler ya da membran aracılı reseptörler ile endokrin bozucu kimyasalların (EBK) etkileşmesinde hücresel yolaklar

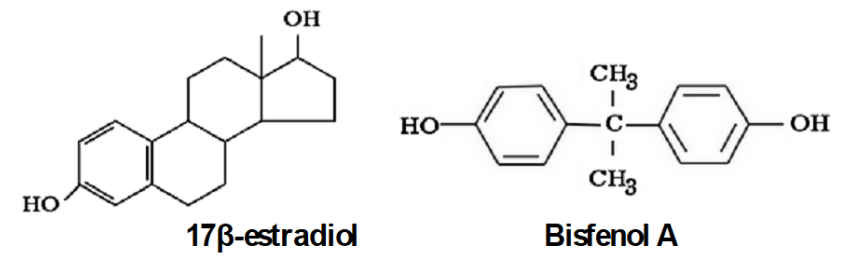

Şekil 3. $17 \beta$ estradiol ve Bisfenol A (BFA)'nın yapısal benzerliği.

Yapılan çalışmalarda, in vitro sistemlerde BFA'nın ER $\alpha$ ile bağlanmak için $17 \beta$ estradiol ile yarıştığı ve insan meme kanseri hücrelerinin (MCF-7) proliferasyonunu uyardığ 1 tespit edilmiştir. $\mathrm{Bu}$ sonuçlar, BFA'nın in vitro ortamda östrojenin bazı eylemlerini taklit ettiğini kanıtlar niteliktedir. BFA yalnızca östrojenin bir taklidi değil, aynı zamanda kendi aktivite spektrumunu üretmek için ER $\alpha$ ile etkileşim kurabilen bir maddedir (Gould ve ark., 1998). 1999 yılında yapılan bir çalışmada, BFA'nın bağlanma afinitesinin $17 \beta$ estradiol'e göre 10000 kat daha düşük olmasına rağmen hem $\mathrm{ER} \alpha$ hem ER $\beta$ ile bağlanabildiği gösterilmiştir (Hiroi ve ark., 1999). BFA'nın ER $\alpha$ ile bağlanmasının proliferasyona sebep olduğu, ER $\beta$ üzerinde ise östrojen-ER $\beta$ kompleksine karşı antagonist etkisi saptanmıştır. Elde edilen bu bilgiler ışığında BFA'nın östrojen aracılı hücre proliferasyonu ve 
ölümü mekanizmasını etkilediği söylenebilmektedir. Yine bir çalışmada BFA'nın ER $\alpha$ - ER $\beta$ dengesini sağlamadan hücreleri sadece proliferasyona yönlendirerek kanser oluşumunu tetikleyebileceği de gösterilmiştir (Ayazgök ve Küçükkilinç, 2017).

\section{Diş Hekimliğinde Bisfenol A}

Diş hekimliğinde klinik başarı elde edebilmek için pratikte kullanılan malzemeler seçilirken kimyasal, fiziksel, biyolojik ve estetik özellikleri göz önüne alınmaktadır. Örneğin çok eski zamanlardan beri restoratif diş hekimliğinde dolgu malzemesi olarak kullanılan amalgam, estetik sebeplerle ve içeriğinde bulunan civanın salınımı ile sağlı üzerine etkilerinden dolayı yerini kompozit rezin materyallere bırakmaktadır. Daha sonra yapılan çalışmalar sonucunda amalgamdan salınan civa miktarının çok düşük olduğu, nörogelişimsel ya da böbrek fonksiyonları üzerinde herhangi bir yan etkisi olmadığı kanıtlanmıştır (Akyüz ve ark., 2011).

Rezin esaslı polimerler diş hekimliğinde protetik apareyler, yapıştırıcı simanlar, ölçü malzemeleri, restoratif materyaller gibi geniş kullanım alanlarına yayılmıştır (Harorl1, 2009). BFA ve türevleri ise dental rezin esaslı materyallerden kompozit dolguların içeriğinde ve özellikle pedodontide kullanımı yaygın olan ve gün geçtikçe artan oranlarda kullanıma sahip olan fissür örtücülerin yapısında bulunmaktadır. Bu rezinlerin yerleştirilmesinden sonra BFA salınımı olduğu çalışmalarla gösterilmiştir (Akyüz ve ark., 2011).

\section{Diş Hekimliğinde Polimerler ve Monomerler}

Her birine 'monomer' ismi verilen, aynı kimyasal yapılı çok sayıda birimin tekrarı ile oluşan polimerler ile günlük hayatta otomobil lastikleri, DNA, sentetik rezinler gibi çok farklı alanlarda karşılaşılmaktadır. Monomerlerden polimer oluşma sürecine polimerizasyon ismi verilmekte ve ideal olarak tüm monomerler harcanıp polimer ortaya çıkana kadar polimerizasyonun devam etmesi beklenmektedir. Ancak polimerizasyon sonucunda ortamda 'artık monomer' adı verilen reaksiyona girmemiş monomerler kalabilmektedir (Harorl1, 2009). Ortamda kalan artık monomerler ve materyallerin yapısal bozunmaları sonucu salınan bileşenler dokularda biyolojik reaksiyonlara ve sağlık üzerinde çeşitli etkilere sebep olabilmektedir (Atalayın ve ark., 2016). 1900'lerin başlarında sentezlenip polimerize edilen metakrilik asit ve metil metakrilat (MMA) zamanla diş hekimliğinde en yaygın kullanılan polimerler haline gelmiştir, kompozitlerin çoğunluğu metakrilat esaslı polimerlerden oluşmaktadır. 1900'lerin ortalarına doğru epoksi rezin ve daha da önemlisi günümüzde birçok restoratif materyalin yapı taşını oluşturan BFA Glisidilmetakrilat (Bis-GMA) geliştirilmiştir (Şekil 4) (Harorl1, 2009; Fleisch ve ark., 2010).<smiles>CC(C)(c1ccc(O)cc1)c1ccc(O)cc1</smiles><smiles>C=C(C)C(=O)OCC(O)COc1ccc(C(C)(C)c2ccc(OCC(O)COC(=O)C(=C)C)cc2)cc1</smiles>

Şekil 4. Bis-GMA'nın kimyasal yapısı

\section{Rezin Esaslı Kompozitlerin ve Fissür Örtücülerin İçeriği}

Günümüzde rezin esaslı kompozitler, çürük, hipoplazik dişlerin restorasyonu ve estetik sebeplerle en sık kullanımı tercih edilen materyallerdir. Kısaca 'kompozit' olarak adlandırılan rezin esaslı kompozit restoratif materyaller temelde; polimerler içeren organik rezin matriks ve inorganik doldurucu olmak üzere iki ana komponentten oluşurlar. İnorganik doldurucu içermeyen kompozitler ise 'örtücüler' olarak bilinirler (Akyüz ve ark., 2011; Olea ve ark., 1996; Harorl1, 2009). Fissür örtücüler, dişlerin çürük oluşumuna en uygun bölgeleri olan oklüzal yüzeylerdeki pit ve fissürlere uygulanan materyallerdir. Rezin esaslı fissür örtücüler ve cam iyonomer esaslı fissür örtücüler klinik pratiğinde en sık tercih edilenlerdir (Akyüz ve ark., 2011; Ünlügenç ve Bolgül, 2019).

Kompozit ve fissür örtücülerin aktif bileşeni ve ana maddesi olan organik rezin matriks; Bis-GMA, Uretan Dimetakrilat (UDMA), Trietilen Glikol Dimetakrilat (TEGDMA) gibi monomerler içermektedir (Akyüz ve ark., 2011; Harorl1, 2009). Yüksek molekül ağırlığından dolayı oldukça visköz bir yapıya sahip olan Bis-GMA'ya visközite kontrolü için MMA, TEGDMA gibi monomerler ilave 
edilerek istenilen şekilde kompozit veya fissür örtücüler elde edilebilmektedir (Akyüz ve ark., 2011).

BFA, kompozit rezinlerin ve fissür örtücülerin rezin yapısının bir monomeridir (Şekil 3) (Akyüz ve ark., 2011). Endüstriyel çalışmalar kompozitler ve fissür örtücüler için önemli gelişmeler ortaya koymuşsa da polimerizasyon sonrası artık monomer miktarını tamamen elimine edememiştir, bu materyallerden artık monomerlerin salınması ve BFA açığa çıkması nedeniyle dokulara toksik etkileri olabileceği düşünülmektedir (Gül ve Akgül, 2013; Akyüz ve ark., 2011).

\section{Biyouyumluluk}

Biyouyumluluk, uygulanan malzemenin dokular ile etkileşimi sonrası sistemik veya lokal olarak toksik, alerjik, mutajenik veya karsinojenik herhangi bir etki oluşturmaması anlamına gelmektedir. Biyouyumlu bir materyal, dokular üzerinde tamamen etkisiz olmasa da en azından tolere edilebilir düzeyde bir etki oluşturması beklenmektedir (Atalayın ve ark., 2016).

Diş hekimliğinde sıklıkla kullanılan malzemeler olan kompozitler ve fissür örtücülerde de yetersiz polimerizasyon sonucu ağız ortamına artık monomer yani BFA salınımı gözlenmekte ve sağlık için potansiyel tehlike oluşturabileceği düşünüldüğünden, kısa ve uzun dönemde bu materyallerde meydana gelebilecek erozyon ve bozunma sonucu monomer salınımı yaşanabileceğinden biyouyumluluğu araştırılmaktadır (Atalayın ve ark., 2016; Akyüz ve ark., 2011; Gül ve Akgül, 2013). Kullanılan dental materyallerin lokal tesirleri pulpa, periodonsiyum, apeks, mukoza ve dil gibi hemen çevre dokularda gözlemlenebilirken; salınan materyallerin vücuda çeşitli yollarla dağılması sonucu, materyale maruziyet süresi ve miktarına ve bazı diğer etkenlere de bağlı olarak sistemik tesirler ortaya çıkabilmektedir (Harorlı, 2009). Bilim insanlarının yapmış olduğu çalışmalarla, rezin kompozit ve fissür örtücülerden salınan monomerin sistemik bir yan etki oluşturacak düzeyde olmadığı sonucuna varılmıştır (Atalayın ve ark., 2016).

\section{TARTIŞMA VE SONUÇ}

Yüksek darbe dayanıklılığı, sağlamlığı, polimerlerle ideal uyumluluğu, şeffaflığ 1 gibi özelliklerinden dolayı dünyada en çok üretilen ve çevreye yayılan kimyasalların başında BFA olduğu bilinmektedir. Dental ve tıbbi malzemelerin de içeriğinde bulunmasıyla BFA'ya maruziyet yolları son yıllarda artış göstermiştir. Literatürdeki en geniş veri grupları incelendiğinde, BFA kullanımının özellikle çocuklar için üretilen ürünlerde sınırlandırılması gibi önlemler ile çocuklarda idrar BFA düzeylerinin yıllar içerisinde azalma eğilimi gösterdiği ortaya konmuştur. $\mathrm{Bu}$ düzeylerde azalma görülmüş olsa da EBK'ların farklı dozyanıt ilişkileri sergileyebileceği bilinmektedir (İnce, 2017). BFA'ya mesleki açıdan maruz kalmayan popülasyonda yapılan çalışmaların çoğunda düşük doz maruziyetin dahi sağlık üzerindeki olumsuz tesirleri ispatlanmaktadır (Sözlü ve Akdevelioğlu, 2018).

BFA ve Bisfenol A - dimetakrilata diş hekimliğinde kullanılan rezin bazlı kompozit ve fissür örtücüler vasıtası ile maruz kalınanabileceği bildirilmiştir. Molar dişlere fisssür örtücü uygulaması durumunda tükürükte BFA'ya rastlandığı gösterilmiştir (Olea ve ark., 1996).

Sağlıkl1, daha önce fissür örtücü ve kompozit rezin restorasyon öyküsü bulunmayan kişilerde; fissür örtücü yerleştirmesinden hemen önce ve yerleştirdikten 1 ve 3 saat sonra toplanan tükürük örneklerinde BFA saptanmış, 3 saatten sonraki örneklerde ise BFA saptanmamıştır. Bu çalışma ile fissür örtücü uygulamasından sonra, ağızdan salınan BFA'nın dolaşımda saptanamayan miktarlarda bulunabileceği gösterilmiştir. Ancak fissür örtücülerin potansiyel östrojenitesi ile ilgili kesin bir sonuca varılamamıştır (Fung ve ark., 2000).

Sasaki ve arkadaşları 21 denekte kompozit dolgu yerleştirilmeden hemen önce, hemen sonra ve 1 lik suyla gargara yapılmasının ardından tükürük örnekleri toplanmış; tüm numunelerde dolgu yerleştirilmesinden hemen sonra taban çizgisine kıyasla daha yüksek bir BFA konsantrasyonu göstermiş ancak gargara yapılmasından sonra bu konsantrasyonların önemli ölçüde azaldığı tespit edilmiştir. Araştırmacılar etkili gargara yapılmasının BFA'ya maruziyeti ve olası östrojenik etkileri azaltabileceği sonucuna ulaşmışlardır (Sasaki ve ark., 2005).

Chung ve arkadaşları ise Güney Kore'de 8-9 yaşlarındaki 495 çocukları muayene edip rezin bazlı kompozit ve fissür örtücü ile kaplı yüzey sayılarına göre $(0,1-5,6-10$, $11+$ ) dört gruba ayırmışlar ve topladıkları idrar örnekleri analizleri sonucunda 11 veya daha fazla yüzeyi kompozit ve fissür örtücü ile restore edilmiş çocuklarda, sıfır restore edilmiş yüzeye sahip çocuklara göre anlamlı düzeyde daha yüksek BFA konsantrasyonları olduğunu tespit etmişlerdir. $\mathrm{Bu}$ çalışmanın sonunda dişlerde çok sayıda rezin bazlı 
kompozit ya da fissür örtücü yüzeye sahip olmanın çocuklarda idrar BFA konsantrasyonlarını arttırabileceği sonucuna ulaşmışlardır (Chung ve ark., 2012).

Üstündağ ve arkadaşları BFA ve polietilen tereftalat plastiklerin yapımında kullanılan di-(2 - etilheksil ) ftalat (DEHP)'ın zebra balığı embriyolarında oksidanantioksidan dengesi ve toksik etkilerini incelemişlerdir. BFA ve DEHP'ye maruz kalan zebra balığı embriyolarında oksidan-antioksidan dengesi ile hücre proliferasyonu, büyümesi, farklılaşması ve apoptoz ile ilgili birçok gen ürününün ekspresyonunu düzenleyen bir transkripsiyon faktörü olan c-myc proto-onkogeni arasındaki ilişki araştırılmış, BFA ve DEHP'ye maruz kalan embriyolarda oksidan-antioksidan dengesinin bozulduğu tespit edilmiş ve bu dengenin bozulmasinın artan c-myc ekspresyonu ile ilgili olduğu belirlenmiştir. BFA ve DEHP'nin sağlıkla ilgili etkileri, potansiyel toksik etkilerini de göstermektedir ve ortaya konan bu mekanizmanın bu kimyasalların toksik etkileri için önemli olabileceği ifade edilmiştir (Üstündağ ve ark., 2017).

Yine Üstündağ ve arkadaşları başka bir çalışmada zebra balığı embriyolarında BFA ve DEHP maruziyeti sonucunda Wnt/ß-katenin sinyal yolu ile apoptoz arasındaki bağlantıyı araştırmışlardır. Wnt/ $\beta$-katenin sinyal yolunun embriyonik gelişim esnasında hücre proliferasyonu, spesifikasyonu ve hücre kaderinin belirlenmesinde önemli rollere sahip olduğu ve bu sinyal yolunun apoptoz ile bağlantılı olduğu gösterilmiştir. Çalışmanın sonucunda BFA'ya maruz kalan embriyolarda apoptoz gözlendiği bildirilmiştir (Üstündağ ve ark., 2017).

Yapılan bir çalışmada, köpeklerde dilaltı maruziyeti ile BFA'nın oral mukozadan çok hızlı ve verimli bir şekilde emilebildiği gösterilmiş; BFA'nın bu emiliminin yaygın olarak bilinen gastrointestinal sistemden emiliminden çok daha yüksek maruziyetlere yol açabileceği tespit edilmiştir (Löfroth ve ark., 2019).

Öz, BFA ve yeni bir ER antagonisti olan antiöstrojen türlerinden Fulvestrant (ICI) kimyasalının HEPG2 insan hepatoma hücrelerine uygulanmasıyla ortaya çıkabilecek çeşitli etkileri incelenmiş; düşük dozda BFA'nın hücre proliferasyonu ve migrasyonunu arttırdığını, BFA'nın ICI'nın sitotoksik etkisini arttırdığını, BFA ve ICI kombinasyonunun uygulanmasının apoptozu arttırdığını bildirmiştir (Öz, 2020).

Çoğu EBK'nin düşük dozlarda daha etkin olduğu bilinmektedir. Toksikoloji çalışmalarında yüksek dozlarda görülmeyen yan tesirlerin düşük dozlarda gözlendiği bildirilmiştir. Çalışmalar sonucunda elde edilen bu kanıtlar herhangi bir EBK için 'güvenli doz' olmadığ 1 anlamına gelmektedir. Yapılan araştırma ve çalışmalarda alım miktarı belirlenen TDI'nın çok altında olmasına rağmen, BFA ile sağlık üzerinde görülen birçok yan etki arasında bağlantı kurulabilmesi bu hipotezle açılanabilmektedir (İnce, 2017). Düşük doz BFA'nın beynin nörokimyasını etkilediği bilinmekte ancak bu düşük dozlarda ortaya çıkan etkilerin reseptör aracılı yanıtlarla ilişkili olduğu varsayılıp kesin moleküler mekanizması bilinmemektedir (Öz, 2020).

Sonuç olarak BFA'nın insan sağlığı üzerinde östrojenik etkileri olduğu, diş hekimliğine kullanılan dental kompozit ve fissür örtücülerden de BFA sızıntısı olduğu bilinmekte ancak günlük yaşamdan yaygın BFA maruziyetinin yanında kullanılan dental materyallerdeki BFA sızıntısının insan sağlığını tehdit edici mekanizmalara etkisinin yeterli düzeyde tespit edilebilmesi için daha çok çalışma ve araştırmaya ihtiyaç bulunmaktadır. BFA'nın düşük dozlarda bile bebek ve çocuk gelişimini olumsuz etkileyebileceği göz önünde bulundurularak, hamile kadınlarda dental kompozit restorasyonlar ile tedavinin mümkün olduğunca ertelenmesi veya mümkün olan en az düzeyde uygulanması, çocuklarda çürük gelişiminin engellenmesi ve azaltılabilmesi için flor uygulamaları gibi farklı yöntemlerin de göz önünde bulundurulması, halkın yaygın BFA maruziyeti konusunda bilgilendirilmesi ve bilinçlendirilmesi, rezin esaslı kompozit ve fissür örtücüler uygulanırken ideal polimerizasyon için firma önerilerine tam uyulması, uygulama sonrası gargara yapılması gibi önlemlerin uygulanabileceğini düşünmekteyiz.

\section{KAYNAKLAR}

1. Akyüz S, Yarat A, Egil E. Bisfenol-A içerikli dental materyallere güncel yaklaşım. Clinical and Experimental Health Sciences. 2011; 1(3), 190-195.

2. Alonso-Magdalena P, Vieira E, Soriano S, Menes L, Burks D, Quesada I, Nadal A. Bisphenol A exposure during pregnancy disrupts glucose homeostasis in mothers and adult male offspring. Environmental health perspectives. 2010; 118(9), 1243-1250.

3. Atalayın Ç, Tezel H, Ergücü Z. Rezin Esaslı Dental Materyallerin Sitotoksisitesine Genel Bir Bakış. Ege Üniversitesi Dişhekimliği Fakültesi Dergisi. 2016; 37_2: 4753.

4. Ayazgök B, Küçükkilinç TT. Düşük Doz Bisfenol A’nın Büyük Etkileri. FABAD Journal of Pharmaceutical Sciences. 2017; 42(2), 139. 
5. Battal D. Mersin İlinde Yaşayan Bireylerdeki Bisfenol A Düzeyinin Belirlenmesi. Mersin Üniversitesi. Sağlık Bilimleri Enstitüsü, Yüksek Lisans Tezi, 2012.

6. Bergman A, Heindel JJ, Jobling S, Kidd K, Zoeller TR, World Health Organization. State of the science of endocrine disrupting chemicals 2012. World Health Organization. 2013.

7. Bondesson M, Jönsson J, Pongratz I, Olea N, Cravedi JP, Zalko D, Manthey D vd. A Cascade of effects of bisphenol A. Reproductive toxicology (Elmsford, NY). 2009; 28(4), 563.

8. Carwile JL, Michels KB. Urinary bisphenol A and obesity: NHANES 2003-2006. Environmental research. 2011; 111(6), 825-830.

9. Choi SM, Yoo SD, Lee BM. Toxicological characteristics of endocrine-disrupting chemicals: developmental toxicity, carcinogenicity, and mutagenicity. Journal of Toxicology and Environmental Health, Part B. 2004; 7(1), 1-23.

10. Chung SY, Kwon H, Choi YH, Karmaus W, Merchant AT, Song KB, Kang D vd. Dental composite fillings and bisphenol A among children: a survey in South Korea. International dental journal. 2012; 62(2), 65-69.

11. Colborn T. Neurodevelopment and endocrine disruption. Environmental health perspectives. 2004; 112(9), 944-949.

12. Corrales J, Kristofco LA, Steele WB, Yates BS, Breed CS, Williams ES, Brooks BW. Global assessment of bisphenol A in the environment: review and analysis of its occurrence and bioaccumulation. Dose-Response. 2015; 13(3), 155.932.5815598308.

13. Davis DL, Bradlow HL, Wolff M, Woodruff T, Hoel DG, Anton-Culver H. Medical hypothesis: xenoestrogens as preventable causes of breast cancer. Environmental health perspectives. 1993; 101(5), 372-377.

14. Diamanti-Kandarakis E, Bourguignon JP, Giudice LC, Hauser R, Prins GS, Soto AM, Gore AC vd. Endocrinedisrupting chemicals: an Endocrine Society scientific statement. Endocrine reviews. 2009; 30(4), 293-342.

15. Dodds EC, Lawson W. Synthetic strogenic agents without the phenanthrene nucleus. Nature. 1936; 137(3476), 996-996.

16. Durmaz E, BK G. Çevresel bir endokrin bozucu: Bisfenol A ve toksik etkilerinin değerlendirilmesi. Çocuk Sağlığ1 ve Hastalıkları Dergisi. 2013; 56, 192-9.

17. European Food Safety Authority (EFSA), 2015. No consumer health risk from bisphenol A exposure. Erişim adresi: https:// www.efsa.europa.eu/en/press/news/150121 Erişim tarihi: 20 Kasim 2020.

18. Fendoğlu BY, Koçer-Gümüşel B, Erkekoğlu P. Endokrin Bozucu Kimyasal Maddeler ve Kanser Arasındaki İlişkinin Değerlendirilmesi ve Korunma Önerileri. Hacettepe Üniversitesi Eczacılık Fakültesi Dergisi. 2018; 39(1), 44-57.

19. Fendoğlu BY, Koçer-Gümüşel B, Erkekoğlu P. Endokrin Bozucu Kimyasal Maddelere ve Etki Mekanizmalarına Genel Bir Bakış. Hacettepe Üniversitesi Eczacılık Fakültesi Dergisi. 2017; 39(1), 30-43.

20. Fernandez MF, Arrebola JP, Taoufiki J, Navalón A, Ballesteros O, Pulgar R, Olea N vd. Bisphenol-A and chlorinated derivatives in adipose tissue of women. Reproductive toxicology. 2007; 24(2), 259-264.
21. Fleisch AF, Sheffield PE, Chinn C, Edelstein BL, Landrigan PJ. Bisphenol A and related compounds in dental materials. Pediatrics. 2010; 126(4), 760-768.

22. Freitas J, Cano P, Craig-Veit C, Goodson ML, Furlow JD, Murk AJ. Detection of thyroid hormone receptor disruptors by a novel stable in vitro reporter gene assay. Toxicology in Vitro. 2011; 25(1), 257-266.

23. Fung EY, Ewoldsen NO, GERMAIN JR HAS, Marx DB, MIAW CL, Siew C, Meyer DM vd. Pharmacokinetics of bisphenol A released from a dental sealant. The journal of the american dental association. 2000; 131(1), 51-58.

24. Gao H, Yang BJ, Li N, Feng LM, Shi XY, Zhao WH, Liu SJ. Bisphenol A and hormone-associated cancers: current progress and perspectives. Medicine. 2015; 94(1).

25. Geens T, Aerts D, Berthot C, Bourguignon JP, Goeyens L, Lecomte P, Van Loco J vd. A review of dietary and non-dietary exposure to bisphenol-A. Food and chemical toxicology. 2012; 50(10), 3725-3740.

26. Ginsberg G, Rice DC. Does rapid metabolism ensure negligible risk from bisphenol A?. Environmental health perspectives. 2009; 117(11), 1639-1643.

27. Gore AC, Chappell VA, Fenton SE, Flaws JA, Nadal A, Prins GS, Zoeller RT vd. EBK-2: the Endocrine Society's second scientific statement on endocrine-disrupting chemicals. Endocrine reviews. 2015; 36(6), E1-E150.

28. Gould JC, Leonard LS, Maness SC, Wagner BL, Conner K, Zacharewski T, Gaido KW vd. Bisphenol A interacts with the estrogen receptor $\alpha$ in a distinct manner from estradiol. Molecular and cellular endocrinology. 1998; 142(1-2), 203214.

29. Gül P, Akgül N. Kompozit Materyallerin Biyouyumluluğu Hakkında Literatür Derlemesi. Atatürk Üniversitesi Diş Hekimliği Fakültesi Dergisi. 2013; 23.

30. Harorl1 OT. Triethylene Glycol Dimethacrylate (TEGDMA)'ın Biyouyumluluğunun Hücre Kültürü Yöntemi ile Sitomorfolojik Olarak İncelenmesi. Atatürk Üniversitesi. Sağlık Bilimleri Enstitüsü, Doktora Tezi. 2009.

31. Hiroi H, Tsutsumi O, Momoeda M, Takai Y, Osuga Y, Taketani Y. Differential interactions of bisphenol A and17 $\beta$ estradiol with estrogen receptor $\alpha(\mathrm{ER} \alpha)$ and $\mathrm{ER} \beta$. Endocrine journal. 1999; 46(6), 773-778.

32. İnce OT. Tip I Diyabetli Çocuklarda Bisfenol A Maruziyeti ve İdrar Bisfenol A Düzeyleri. Hacettepe Üniversitesi. Sağlık Bilimleri Enstitüsü, Doktora Tezi. 2017.

33. Kabir ER, Rahman MS, Rahman I. A review on endocrine disruptors and their possible impacts on human health. Environmental toxicology and pharmacology. 2015; 40(1), 241-258.

34. Kang JH, Aasi D, Katayama Y. Bisphenol A in the aquatic environment and its endocrine-disruptive effects on aquatic organisms. Critical reviews in toxicology. 2007; 37(7), 607625 .

35. Kang JH, Katayama Y, Kondo F. Biodegradation or metabolism of bisphenol A: from microorganisms to mammals. Toxicology. 2006; 217(2-3), 81-90. 
36. Konieczna A, Rutkowska A, Rachon D. Health risk of exposure to Bisphenol A (BFA). Roczniki Państwowego Zakładu Higieny. 2015; 66(1).

37. Kuiper GG, Lemmen JG, Carlsson BO, Corton JC, Safe SH, Van Der Saag PT, Gustafsson JA vd. Interaction of estrogenic chemicals and phytoestrogens with estrogen receptor $\beta$. Endocrinology. 1998; 139(10), 4252-4263.

38. La Rocca C, Tait S, Guerranti C, Busani L, Ciardo F, Bergamasco B, Caserta D vd. Exposure to endocrine disruptors and nuclear receptors gene expression in infertile and fertile men from Italian areas with different environmental features. International journal of environmental research and public health. 2015; 12(10), 12426-12445.

39. Lagos-Cabré R, Moreno RD. Contribution of environmental pollutants to male infertily: a working model of germ cell apoptosis induced by plasticizers. Biological research. 2012; 45(1), 5-14.

40. LaKind JS, Goodman M, Mattison DR. Bisphenol A and indicators of obesity, glucose metabolism/type 2 diabetes and cardiovascular disease: a systematic review of epidemiologic research. Critical reviews in toxicology. 2014; 44(2), 121150.

41. Löfroth M, Ghasemimehr M, Falk A, von Steyern PV. Bisphenol $\mathrm{A}$ in dental materials-existence, leakage and biological effects. Heliyon. 2019; 5(5), e01711.

42. Mahamuni D, Shrinithivihahshini ND. Inferring Bisphenol-A influences on estrogen-mediated signalling in estrogen and androgen receptors: an in silico approach. Biocatalysis and Agricultural Biotechnology. 2019; 20, 101178.

43. Marmugi A, Lasserre F, Beuzelin D, Ducheix S, Huc L, Polizzi A, Mselli-Lakhal L vd. Adverse effects of longterm exposure to bisphenol A during adulthood leading to hyperglycaemia and hypercholesterolemia in mice. Toxicology. 2014; 325, 133-143.

44. McKinney C, Rue T, Sathyanarayana S, Martin M, Seminario AL, DeRouen T. Dental sealants and restorations and urinary bisphenol A concentrations in children in the 2003-2004 National Health and Nutrition Examination Survey. The Journal of the American Dental Association. 2014; 145(7), 745-750.

45. McKinney JD, Waller CL. Polychlorinated biphenyls as hormonally active structural analogues. Environmental Health Perspectives. 1994; 102(3), 290-297.

46. McKinney JD, Waller CL. Molecular determinants of hormone mimicry: halogenated aromatic hydrocarbon environmental agents. Journal of Toxicology and Environmental Health, Part B Critical Reviews. 1998; 1(1), 27-58.

47. Miller WR, Sharpe RM. Environmental oestrogens and human reproductive cancers. Endocrine-related cancer. 1998; 5(2), 69-96.

48. Moriyama K, Tagami T, Akamizu T, Usui T, Saijo M, Kanamoto N, Nakao K vd. Thyroid hormone action is disrupted by bisphenol $\mathrm{A}$ as an antagonist. The Journal of Clinical Endocrinology \& Metabolism. 2002; 87(11), 51855190.

49. Olea N, Pulgar R, Pérez P, Olea-Serrano F, Rivas A, NovilloFertrell A, Sonnenschein C vd. Estrogenicity of resin-based composites and sealants used in dentistry. Environmental health perspectives. 1996; 104(3), 298-305.

50. Otlu HG, Türköz Y. Bisphenol A Exposure Routes Metabolism and Toxicity. İnönü Üniversitesi Sağlık Bilimleri Dergisi. 2016; 5(1): 23-28.

51. Öz E. Bisfenol A'nın HEPG2 Hücrelerine Olan Etkilerinin İncelenmesi. Hacettepe Üniversitesi. Sağlık Bilimleri Enstitüsü, Yüksek Lisans Tezi. 2020.

52. Papalou O, Kandaraki EA, Papadakis G, DiamantiKandarakis E. Endocrine disrupting chemicals: an occult mediator of metabolic disease. Frontiers in Endocrinology. 2019; 10, 112.

53. Park MA, Choi KC. Effects of 4-nonylphenol and bisphenol A on stimulation of cell growth via disruption of the transforming growth factor- $\beta$ signaling pathway in ovarian cancer models. Chemical research in toxicology. 2014; 27(1), 119-128.

54. Seiwa C, Nakahara J, Komiyama T, Katsu Y, Iguchi T, Asou H. Bisphenol A exerts thyroid-hormone-like effects on mouse oligodendrocyte precursor cells. Neuroendocrinology. 2004; 80(1), 21-30.

55. Sevencan F, Vaizoğlu SA. Pet ve geri dönüşümü. TSK Koruyucu Hekimlik Bülteni. 2007; 6(4), 307-312.

56. Shelby MD. NTP-CERHR monograph on the potential human reproductive and developmental effects of bisphenol A. Ntp cerhr mon. 2008; (22), v.

57. Snyder RW, Maness SC, Gaido KW, Welsch F, Sumner SC, Fennell TR. Metabolism and disposition of bisphenol A in female rats. Toxicology and applied pharmacology. 2000; 168(3), 225-234.

58. Soto AM, Sonnenschein C. Environmental causes of cancer: endocrine disruptors as carcinogens. Nature Reviews Endocrinology. 2010; 6(7), 363-370.

59. Sözlü S, Akdevelioğlu Y. Bisfenol A (BFA) ve insan üreme sağlığı. Mersin Üniversitesi Sağlık Bilimleri Dergisi. 2018; 11(1), 86-99.

60. Stahlhut RW, Welshons WV, Swan SH. Bisphenol A data in NHANES suggest longer than expected half-life, substantial nonfood exposure, or both. Environmental health perspectives. 2009; 117(5), 784-789.

61. Sun H, Shen OX, Wang XR, Zhou L, Zhen SQ, Chen $\mathrm{XD}$. Anti-thyroid hormone activity of bisphenol A, tetrabromobisphenol A and tetrachlorobisphenol A in an improved reporter gene assay. Toxicology in vitro. 2009; 23(5), 950-954.

62. Ustundag UV, İsmail UNAL, Ates PS, Alturfan AA, Yigitbasi T, Alturfan EE. Oxidant-Antioxidant Status and c-myc Expression in BFA-and DEHP-Exposed Zebrafish Embryos. European Journal of Biology. 2017; 76(1), 26-30.

63. Ünlügenç E, Bolgül B. Güncel Fissür Örtücüler-Literatür Derlemesi. Atatürk Üniversitesi Diş Hekimliği Fakültesi Dergisi. 2019; 30(3), 507-518.

64. Üstündağ ÜV, Ünal İ, Ateş PS, Alturfan AA, Yiğitbaşı T, Emekli-Alturfan E. Bisphenol A and di (2-ethylhexyl) phthalate exert divergent effects on apoptosis and the Wnt/ $\beta$ catenin pathway in zebrafish embryos: A possible mechanism 
of endocrine disrupting chemical action. Toxicology and industrial health. 2017; 33(12), 901-910.

65. Vandenberg LN, Chahoud I, Heindel JJ, Padmanabhan V, Paumgartten FJ, Schoenfelder G. Urinary, circulating, and tissue biomonitoring studies indicate widespread exposure to bisphenol A. Environmental health perspectives. 2010; 118(8), 1055-1070.

66. Vandenberg LN, Colborn T, Hayes TB, Heindel JJ, Jacobs Jr DR, Lee DH, Zoeller RT vd. Hormones and endocrinedisrupting chemicals: low-dose effects and nonmonotonic dose responses. Endocrine reviews. 2012; 33(3), 378-455.

67. Vandenberg LN, Hunt PA, Myers JP, vom Saal FS. Human exposures to bisphenol A: mismatches between data and assumptions. Reviews on environmental health. 2013; 28(1), 37-58.

68. Vandenberg LN, Maffini MV, Sonnenschein C, Rubin BS, Soto AM. Bisphenol-A and the great divide: a review of controversies in the field of endocrine disruption. Endocrine reviews. 2009; 30(1), 75-95.

69. Veiga-Lopez A, Kannan K, Liao C, Ye W, Domino SE, Padmanabhan V. Gender-specific effects on gestational length and birth weight by early pregnancy BFA exposure. The Journal of Clinical Endocrinology \& Metabolism. 2015; 100(11), E1394-E1403.

70. Vom Saal FS, VandeVoort CA, Taylor JA, Welshons WV, Toutain PL, Hunt PA. Bisphenol A (BFA) pharmacokinetics with daily oral bolus or continuous exposure via silastic capsules in pregnant rhesus monkeys: Relevance for human exposures. Reproductive Toxicology. 2014; 45, 105-116.

71. Welshons WV, Nagel SC, vom Saal FS. Large effects from small exposures. III. Endocrine mechanisms mediating effects of bisphenol A at levels of human exposure. Endocrinology. 2006; 147(6), s56-s69.

72. Willhite CC, Ball GL, McLellan CJ. Derivation of a bisphenol A oral reference dose (RfD) and drinking-water equivalent concentration. Journal of Toxicology and Environmental Health, Part B. 2008; 11(2), 69-146.

73. Wioletta RW, Małgorzata R, Karolina N, Milena D, Piotr R, Ewa J. Effect of bisphenol A on human neutrophils immunophenotype. Scientific Reports (Nature Publisher Group). 2020; 10(1).

74. Yaman Ü, Erkekoğlu P, Gümüşel BK. Endokrin Bozucu Kimyasal Maddeler ve Tiroid Üzerine Etkileri: Poliklorlu Bifeniller, Ftalat ve Bisfenol A. Hacettepe Üniversitesi Eczacılık Fakültesi Dergisi.2015; (1), 1-19.

75. Ye X, Pierik FH, Angerer J, Meltzer HM, Jaddoe VW, Tiemeier H, Longnecker MP vd. Levels of metabolites of organophosphate pesticides, phthalates, and bisphenol A in pooled urine specimens from pregnant women participating in the Norwegian Mother and Child Cohort Study (MoBa). International journal of hygiene and environmental health. 2009; 212(5), 481-491.

76. Ye X, Pierik FH, Hauser R, Duty S, Angerer J, Park MM, Steegers EA vd. Urinary metabolite concentrations of organophosphorous pesticides, bisphenol A, and phthalates among pregnant women in Rotterdam, the Netherlands: the Generation R study. Environmental research. 2008; 108(2), 260-267.

77. Ye X, Wong LY, Bishop AM, Calafat AM. Variability of urinary concentrations of bisphenol A in spot samples, first morning voids, and 24-hour collections. Environmental health perspectives. 2011; 119(7), 983-988.

78. Zemheri F, Cevdet UĞUZ. Endokrin bozucu kimyasallar: Nonilfenol ve Bisfenol A. Marmara Fen Bilimleri Dergisi. 2018; 30(1), 71-76.

79. Zoeller RT. Environmental chemicals as thyroid hormone analogues: new studies indicate that thyroid hormone receptors are targets of industrial chemicals?. Molecular and cellular endocrinology. 2005; 242(1-2), 10-15.

80. Zoeller RT, Bansal R, Parris C. Bisphenol-A, an environmental contaminant that acts as a thyroid hormone receptor antagonist in vitro, increases serum thyroxine, and alters RC3/neurogranin expression in the developing rat brain. Endocrinology. 2005; 146(2), 607-612.

81. Zoeller RT, Brown TR, Doan LL, Gore AC, Skakkebaek NE, Soto AM, Vom Saal FS vd. Endocrine-disrupting chemicals and public health protection: a statement of principles from The Endocrine Society. Endocrinology. 2012; 153(9), 40974110 . 